\title{
Wojciech Błażejewski
}

Zakład Metodologii Badań Pedagogicznych

Uniwersytet Rzeszowski

\section{Problemy rozwoju postaw przedsiębiorczych u gimnazjalistów}

Zrozumienie potrzeby wychowywania ludzi przedsiębiorczych jest w krajach Unii Europejskiej zjawiskiem powszechnym, niebudzącym wątpliwości i kontrowersji. Różnice poglądów ujawniają się jedynie przy dokonywaniu wyboru drogi jego realizacji. Taki sam problem wyrażony w pytaniu: jak wychowywać i kształcić człowieka przedsiębiorczego?, występujący w różnych krajach, może być bowiem rozwiązywany różnymi sposobami w zależności od konkretnych warunków - kontekstu kulturowo-społecznego.

Kształcenie i wychowanie to - najogólniej ujmując - proces wspomagania rozwoju intelektualnego, emocjonalnego i wolicjonalnego w sposób uwzględniający wszelkie potrzeby, możliwości, respektujący indywidualne różnice osobowości i zainteresowania.

Człowiek przedsiębiorczy to osoba zdolna do organizowania i prowadzenia działalności gospodarczej oraz podejmowania ryzyka. Oprócz wrodzonych cech osobowości - temperamentu, inteligencji - niezbędne są mu również szczególne umiejętności nabywane i rozwijane w trakcie edukacji szkolnej. Ich rejestr powinien stanowić wskazówkę dla autorów programów nauczania, jakie cele warto i należy w nich uwzględniać.

Cele kształcenia zwykle formułowane są na różnych poziomach ogólności. Jeżeli jednak mają być sprawdzalne i mierzalne, należy je poddać operacjonalizacji - uszczegółowieniu. Od ogólnego sformułowania „,człowiek przedsiębiorczy”, drogą analizowania i uściślania, trzeba dojść do wyszczególnienia wielu cech, które go charakteryzują. Pomocne jest wstępne podzielenie ich na dwie grupy: intelektualne i emocjonalne. W pierwszej grupie jest istotne, by osoba aspirująca do miana przedsiębiorczej zdobyła stosowną wiedzę na temat swojego miejsca i roli w systemie społecznym oraz poznała mechanizmy i prawa rządzące światem przyrody, kultury i cywilizacji, a także te umiejętności, które służą usprawnianiu szeroko rozumianej komunikacji interpersonalnej, bezpiecznemu korzystaniu z nowoczesnych technicznych ułatwień codziennego życia. Druga grupę celów związanych z rozwojem emocjonalnym powinny stanowić przekonania i postawy umożliwiające podejmowanie decyzji zgodnych z kanonem uznawanych powszechnie wartości etyczno-moralnych, w duchu właściwie pojmowanej odpowiedzialności (współodpowiedzialności) za los własny i innych osób.

Oto kluczowe umiejętności przydatne nie tylko potencjalnemu przedsiębiorcy, ale każdemu:

- umiejętność obserwacji otoczenia (planowej, systematycznej, kompleksowej);

- umiejętność logicznego myślenia (analizowania, syntezowania, wnioskowania, prognozowania);

- umiejętność poszukiwania informacji (aktualizacji, weryfikacji, selekcji, wartościowania);

- umiejętność współpracy z innymi osobami w duchu odpowiedzialności, sumienności, uczciwości. 
Rozwój tych umiejętności w procesie kształcenia ogólnego wymaga nie tylko zaangażowania nauczyciela, ale również aktywności ucznia. Współczesna szkoła, mimo rozmaitych deklaracji składanych przy okazji reformy oświaty, nie stwarza w pełni warunków sprzyjających pobudzaniu aktywności uczniów. Powodem tego stanu są:

- niewystarczające kompetencje nauczycieli - hołdujących tradycyjnym, werbalnym metodom podającym;

- charakter modelu nauczania opartego na systemie klasowo-lekcyjnym, podziale treści nauczania na przedmioty według dyscyplin naukowych (historia, fizyka, biologia, geografia);

- konserwatyzm programów nauczania, przejawiający się m.in. przeładowaniem wiedzą faktograficzną, encyklopedyczną, częstokroć oderwaną od realiów współczesności, oraz system oceniania preferujący głównie pojemność pamięci ucznia. ${ }^{1}$

U podstaw realizowanego współcześnie kształcenia ogólnego leży nadal przekonanie, że poszufladkowana na oddzielne przedmioty wiedza szkolna samoczynnie ulegnie integracji w umyśle ucznia, co pozwoli mu stworzyć sobie realny, wyrazisty obraz świata, np. przyrody i techniki, panujących stosunków społecznych, gospodarczych, politycznych. Liczne przykłady potwierdzają, że często tak kształceni absolwenci rozmaitych szkół są bezradni, zagubieni w warunkach gospodarki kapitalistycznej. Bezrobotny, zagubiony, bez wiary, zapału i chęci, przeżywający własny dramat człowiek staje się ciężarem dla społeczeństwa. Nakłady na jego wykształcenie nie przynoszą żadnych pozytywnych efektów.

Współczesnej szkole nadal brak rozwiązań organizacyjnych związanych z odpowiednim doborem treści kształcenia, pozwalających na rzeczywiste integrowanie i strukturyzację wpajanej uczniom wiedzy z rozmaitych przedmiotów. Brak jej zajęć, które pozwalałyby zdobywaną wiedzę sprawdzić w działaniu, rozwinąć umiejętności współpracy z innymi ludźmi, umożliwiać nabieranie doświadczenia w organizowaniu własnej, samodzielnej pracy twórczej. Brak jest zatem okazji do pracy na miarę możliwości ucznia.

Gimnazjaliści to uczniowie, którzy w powszechnej opinii nauczycieli przysparzają najwięcej kłopotów z utrzymaniem dyscypliny w czasie zajęć szkolnych i kontynuowaniem systematycznej nauki. To z ich strony padają często pytania o to, dlaczego właśnie takich przedmiotów i takich treści muszą uczyć się w szkole. Oni także bardzo aktywnie poszukują wiedzy poza szkoła, interesując się najnowszymi udogodnieniami technicznymi. Wykazują się przy tym dużą pomysłowością w dążeniu do zapewnienia sobie dostępu do nich. Stanowią więc grupę młodzieży z jednej strony trudnej do podporządkowania autorytarnym nauczycielom, a z drugiej strony - mobilną, ciekawą świata, zafascynowana technika, pełną energii i zapału. W tej sytuacji warto zastanowić się nad odpowiedzią na pytania:

- Czy te cechy uczniów, stanowiące potencjalne ich walory, są właściwie lub w pełni wykorzystywane w pracy dydaktyczno-wychowawczej?

- Czy kadra pedagogiczna przekonująco i przystępnie realizuje cele edukacji szkolnej?

- Czy w zreformowanej szkole to właśnie nauczyciel powinien być autorem programu nauczania, a więc osobą wytyczającą m.in. cele dydaktyczno-wychowawcze?

Istotne jest, by cele te zostały przez niego sformułowane trafnie, a więc stosownie do aktualnych i antycypowanych potrzeb indywidualnych i społecznych. Nic tak skutecznie nie przekonuje do zasadności zgłębiania konkretnych zagadnień, jak możliwość wykorzystania nabytej wiedzy w działalności praktycznej. Możliwość skutecznego posłużenia się zdobytą w szkole wiedzą może przynosić w praktyce, oprócz osobistej satysfakcji, potrzebę dalszego jej pogłębiania.

\footnotetext{
${ }^{1}$ Por.: J. Wilsz, Mechanizmy samoregulacji w systemie kształcenia, Wydawnictwo WSP w Rzeszowie,
} Częstochowa 1996/1997. 
Kolejne pytanie brzmi: czy uczniowie w gimnazjum mają dość okazji ku temu, by przekonać się, że treści poznawane w ramach edukacji szkolnej mają dla nich sens - znaczenie? Obecnie funkcjonujący model organizacyjno-treściowy kształcenia - przedmiotowo-lekcyjny - bezpośrednio temu nie sprzyja. Nie przyczynia się też do tego, by uczniowie opanowywali umiejętność strukturyzowania swojej wiedzy lub integrowania jej wokół konkretnego zagadnienia czy problemu.

Nie umniejszając roli systematycznego kształcenia przedmiotowego, warto rozważyć możliwość jego częściowego ograniczenia na rzecz wprowadzenia w gimnazjach obowiązkowych zajęć o charakterze interdyscyplinarnym, umożliwiających realizację projektów uczniowskich. Celem nadrzędnym takich zajęć byłyby przede wszystkim:

- zbliżenie treści edukacji szkolnej do realiów życia codziennego, istotnych problemów lokalnych środowisk oraz globalnych, ogólnoludzkich o charakterze np. ekologicznym, społeczno-gospodarczym, politycznym;

- rozwój postaw refleksyjnych, które u młodych, energicznych osób wyrażają się zachowaniami przedsiębiorczymi.

Aby szkoła nie stała się dysfunkcjonalna, powinna zacieśniać partnerską współpracę ze środowiskiem lokalnym, przedstawicielami życia gospodarczego, politycznego, kulturalnego, uwzględniać ich opinie, sugestie na temat tego, co powinny zawierać programy kształcenia. Środowisko powinno inspirować nauczycieli i wychowawców do poruszania zagadnień związanych z problemami życia codziennego, być źródłem pomysłów prac uczniowskich, dzięki którym można rozwijać różne umiejętności i postawy.

Historia rozwoju myśli pedagogicznej zna śmiałe próby zbliżenia szkoły do życia gospodarczego poprzez tzw. uczestnictwo w pracy. Dbałość o to, by młodego człowieka należycie przygotować do samodzielnego utrzymania się, zaznaczyła się już wyraźnie w XVII w., by w XIX w. zyskać uznanie m.in. działaczy Rewolucji Francuskiej, Komisji Edukacji Narodowej (Stanisław Staszic), pedagogów: Jana Pestalozziego i Filipa Emanuela Fellenberga. Na początku XX w. amerykański pedagog John Dewey pisał: ,pierwsze zadanie szkoły polega na zaprawianiu dzieci do wspólnego działania i wzajemnej pomocy w życiu, na zaszczepieniu im poczucia wzajemnej zależności i na dopomaganiu im praktycznie do stwarzania warunków dla wprowadzania w czyn tego nastawienia". ${ }^{2}$ Jego działalność i poglądy znajdowały naśladowców na całym świecie, przekonanych do celowości zapewnienia ścisłego związku szkoły z życiem i uczenia się przez działanie - learning by doing.

W eksperymentalnych szkołach zrezygnowano z przekazywania wiedzy według oddzielnych przedmiotów na rzecz organizowania czynności uczniów wokół określonego tematu, zwanego także projektem - wykorzystując naturalną aktywność i zainteresowania dzieci. U podstaw takiej organizacji nauczania leżało przekonanie, że decydujący wpływ na skuteczność szkolnego nauczania i wychowania ma własne doświadczenie uczniów. Uczenie się w trakcie wspólnego realizowania interesującego projektu - gdy sami uczestnicy wybierają temat, formułują cele działania, dobierają metody pracy, organizują przebieg realizacji, oceniają siebie i innych rozliczając skrupulatnie z terminowości, oryginalności wykonania - przynosi znacznie lepsze wyniki niż bierna reprodukcja wiedzy.

Cechy niezbędne przyszłemu przedsiębiorcy to przede wszystkim aktywność, pomysłowość, odwaga i ufność w możliwości swojego rozumu. Mogą się one z powodzeniem rozwijać od najwcześniejszych lat pobytu dziecka w szkole, pod warunkiem, że w szkole zostaną stworzone

${ }^{2}$ J. Dewey, Moje pedagogiczne credo. Szkoła a społeczeństwo, Książnica-Atlas, Lwów-Warszawa (b.r.), s. 107. 
sprzyjające warunki. Ciaggle jednak brak jest woli ku temu, by nawet początkowo, na zasadzie ograniczonych eksperymentów pedagogicznych, wprowadzać na szerszą skalę obowiązkowe zajęcia o charakterze projektów interdyscyplinarnych. Śmiałe nauczycielskie inicjatywy w tej dziedzinie skutecznie hamują bariery biurokratyczne: niedostosowany do potrzeb system oceniania, brak przepisów dotyczących wymagań, jakie powinni spełniać nauczyciele prowadzący tego rodzaju lekcje, oraz brak środków finansowych, słabo rozwinięta współpraca szkół podstawowych i gimnazjów ze środowiskiem lokalnym: pracodawcami, samorządowcami, artystami, pisarzami itd.

W Polsce brakuje atrakcyjnej oferty szkolnictwa alternatywnego. System kształcenia tworzą głównie tradycyjne, skostniałe, z uwagi na niską efektywność bardzo drogie instytucje. Efektywność kształcenia to w najogólniejszym ujęciu stosunek uzyskanych efektów do poniesionych kosztów. Trudno mówić o efektach, gdy absolwent zdobył wiedzę, ale z niej nie korzysta, i nie umożliwia mu ona podjęcia pracy, znalezienia środków do życia bądź samokształcenia. Efektywność kształcenia jest zależna od wielu istotnych czynników o charakterze ekonomicznym (zarządzania, finansowania) oraz pozaekonomicznym - pedagogicznym. Planowanie, organizowanie, motywowanie kadry i drobiazgowa kontrola procesu edukacji nie są w stanie wpłynąć na poprawę jego efektywności, gdy kształcenie odbywa się według programów nauczania nieprzystających do współczesnych potrzeb i wyzwań przyszłości. Przyrost wiedzy jest tak szybki, że mimo starań wszystkiego nie da się pomieścić, a tym bardziej w pełni zrealizować na szkolnych lekcjach.

Jeśli zamierza się kształcić więcej osób przedsiębiorczych, zdolnych samodzielnie zadbać o swój los, warto podjąć trud krytycznej analizy programów nauczania - zawartych w nich celów i treści, a także zestawów przedmiotów nauczania, wśród których powinny się znaleźć zajęcia pozwalające na integrowanie wiedzy, rozwijające operatywność, umiejętności organizatorskie, komunikacyjne - tak dzisiaj niezbędne ludziom młodym poszukującym swego miejsca w życiu. W tym celu niezbędny jest udział w pracach projektowych nad programami nauczania nie tylko pedagogów, którzy nie zawsze znają wystarczająco potrzeby rynku pracy, oczekiwania pracodawców i prawdopodobnie także i aspiracje swoich uczniów, ale także innych osób.

Do negatywnych zjawisk powszechnych w polskiej szkole, m.in. bierności i apatii uczniów, podporządkowania się utrwalonym rytuałom przekazywania i egzekwowania wiedzy, zaliczane są także: izolacja rodziców od życia szkolnego i obarczanie przez nich nauczycieli i władze państwowe pełną odpowiedzialnością za jakość i efekty kształcenia, a także słabe zainteresowanie środowisk pracodawców kształceniem ogólnym.

Ugruntowaną od lat polską tradycjąjest traktowanie edukacji młodych jako obowiązku przede wszystkim państwa. Wiele krajów europejskich traktuje to jednak odmiennie; dobrym przykładem może być Wielka Brytania, gdzie edukacja jest głównie obowiązkiem społecznym, społeczności lokalnej i rodziców, a jego realizację państwo wspiera. Takie podejście wymaga zrozumienia istoty odpowiedzialnej współpracy różnych podmiotów (rodziców, przedstawicieli administracji lokalnej, świata kultury i biznesu) w dziedzinie konstruowania programów i planów nauczania. Kluczowe decyzje podejmowane są zatem kolegialnie, po szerokich konsultacjach. Stwarza to warunki do takiego realizowania kształcenia na wszystkich szczeblach, by odpowiadało potrzebom i aspiracjom zainteresowanych stron.

Szkolne wychowanie przez pracę i do pracy nie jest dla pedagogów polskich i zagranicznych pojęciem nowym i nieznanym; przeciwnie, stanowi treść subdyscypliny pedagogicznej-pedagogiki pracy.

Trudności ze znalezieniem pracy, zwłaszcza przez osoby szukające jej po raz pierwszy zaraz po ukończeniu szkoły, powodują że znaczna część młodzieży nie ma gdzie nauczyć się pracować 
i zdobyć nawet najskromniejszego doświadczenia zawodowego. Pogarsza to i tak małe szanse na ich zatrudnienie bądź może się istotnie przyczynić do wejścia na „złą drogę” w poszukiwaniu niezbędnych do życia środków.

Dopóki pracodawcy nie będą zainteresowani kształceniem młodzieży i zatrudnianiem absolwentów, a szkoła nie wyjdzie im naprzeciw, wyposażając swoich wychowanków w niezbędne początkującemu pracownikowi kompetencje, dopóty sytuacja na pewno się nie poprawi. Potrzeba porozumienia obu stron, szkoły i pracodawców, na płaszczyźnie koncepcji programów nauczania jest oczywista. Podejmując trud stworzenia własnego przedsiębiorstwa, przedsiębiorca musi być zdolny do wytężonej pracy w nienormowanym czasie, do poszukiwania informacji i krytycznej oceny ich wartości, do planowania własnego doskonalenia i rozwoju zawodowego. Dobra szkoła powinna go do tego przygotować poprzez systematyczny trening w rozwiązywaniu nie tylko tzw. szkolnych sztucznych problemów, ale poprzez aktywny udział w zadaniach na rzecz np. własnego środowiska lokalnego.

Budującym przykładem aktywizacji i jednocześnie wychowywania uczniów, uatrakcyjniania nauczania poprzez wiązanie teorii z praktyka, rozwijania myślenia twórczego, przedsiębiorczości, odpowiedzialności i pomysłowości, była realizacja w Polsce wspólnie z dwunastoma krajami Europy (Rosja, Estonią, Łotwa, Litwą, Węgrami, Słowacją, Czechami, Szkocją, Szwecją, Finlandią, Danią i Norwegią) międzynarodowego projektu Air Pollution Project Europe, przeprowadzonego po raz pierwszy w 1992 r. Dzieci i młodzież współpracowały z naukowcami w ogromnym przedsięwzięciu - sporządzeniu na podstawie szczegółowych pomiarów europejskiej mapy skażeń środowiska kwaśnymi opadami i ozonem.

Współczesne wyzwania stawiają przed nauczycielami, zwłaszcza w nowych typach szkół (gimnazjach), nowe zadania i powodują, że oprócz tradycyjnie pełnionych dotąd ról wykładowców, opiekunów i wychowawców, stają się oni przewodnikami uczniów po świecie złożonych stosunków społecznych, układów politycznych, tendencji i trendów rozwojowych, doradcami zawodowymi, powiernikami aspiracji i marzeń o karierze życiowej.

Jakościowo nowe role i zadania oraz niesłabnące zaufanie społeczne do edukacji sprawiaja, że kształcenie nauczycieli na miarę potrzeb i nadziei musi być procesem rozciągniętym na cały okres aktywności zawodowej. Doskonalenie zawodowe w ramach kształcenia ustawicznego powinno obejmować uzupełnianie wiedzy merytorycznej, narastającej lawinowo wraz z dynamicznym postępem naukowo-technicznym, oraz rozwijanie kompetencji niezbędnych do zrozumienia istoty zmian zachodzących w profilu psychologicznym uczniów, ich rodziców, a także w kulturze i cywilizacji ulegającej nieuchronnej globalizacji.

Nauczyciel na miarę XXI w. - zwłaszcza nauczyciel gimnazjalny pracujący z młodzieżą w trudnym okresie rozwoju fizycznego i psychicznego - nie może być osobą zamkniętą w kręgu własnych życiowych problemów, odtwarzającą w pracy zawodowej dokładnie to, czego sam doświadczał kilkadziesiąt lat wcześniej, jako uczeń. Europejska kadra nauczycielska starzeje się. Nasuwa się pytanie o skutki tego zjawiska dla jakości i efektywności kształcenia i wychowania. Wraz z wiekiem przybywa doświadczenia i rutyny, ale narasta zmęczenie, pojawiają się symptomy wypalenia zawodowego, zmęczenia, a nawet bezradności wobec szybkich zmian kulturowo-cywilizacyjnych. Czy doskonalenie zawodowe jest w stanie sprawić, by te procesy spowalniać bądź odwracać? Warto rozważyć ten problem chociażby przy okazji rozmaitych propozycji i planów wydłużania czasu aktywności zawodowej nauczycieli.

Z gimnazjów napływają niepokojące sygnały o piętrzących się przed nauczycielami trudnościach z utrzymaniem dyscypliny wśród wychowanków i ich coraz słabszych osiagnięciach w nauce, na które nauczyciele nie znajdują środków zaradczych. Postępująca demoralizacja 
uczniów gimnazjów jest zjawiskiem znanym, a jego przyczyn często (niesłusznie) upatruje się głównie w nieudolności pedagogów. Zjawisko to ma przyczyny znacznie głębsze, leżące w sferze polityki społecznej.

\section{Podsumowanie}

Zjawisko globalizacji, demokratyzacji, liberalizacji życia, zmiany gospodarczo-społeczne, postęp naukowo-techniczny sprawiają że mimo podejmowania reform systemów oświatowych, wprowadzane zmiany są spóźnione w stosunku do aktualnych i antycypowanych potrzeb indywidualnych i społecznych. Edukacja młodych trwa długo, jest droga, nie uwzględnia w dostatecznym stopniu rozwijania umiejętności i postaw niezbędnych już dzisiaj. Ignoruje się to, że gimnazjalista w dorosłe życie wejdzie za lat kilka. Zważywszy na dynamikę rozwoju cywilizacyjnego oznacza to, że młody człowiek stanie wówczas wobec konieczności rozwiązywania nowych problemów, być może obecnie nieprzewidywalnych. W jakim stopniu pomoże mu w tym tradycyjna edukacja szkolna, nastawiona jedynie na ułatwienie adaptacji do zastanych obecnie warunków życia?

Budowa społeczeństwa w pełni demokratycznego, opartego na wiedzy, wymaga edukacji służącej rozwijaniu postaw refleksyjnych, przedsiębiorczych, odpowiedzialnych, respektujących kanon ogólnoludzkich wartości etyczno-moralnych. Umiejętności pokojowego współistnienia ludzi różnych kultur, partnerstwa, współpracy, brania odpowiedzialności za losy własne i innych oraz środowiska, mogą być rozwijane tylko w takich szkołach, które oprócz pracy dydaktycznej podejmą trud świadomego wychowywania, umiejętnie łącząc zalety kształcenia przedmiotowego z walorami interdyscyplinarnych projektów, których tematyka będzie wynikiem szerokich konsultacji pedagogów ze wszystkimi, którym przyszłość młodych pokoleń nie jest obojętna.

\section{Literatura}

1. Bogaj A. (red.), Realia i perspektywy reform oświatowych, IBE, Warszawa 1997.

2. Dewey J., Moje pedagogiczne credo. Szkoła a społeczeństwo, Książnica-Atlas, Lwów-Warszawa (b.r.), s. 107.

3. Dybek H., Doradztwo metodyczne i doskonalenie zawodowe nauczycieli, Oficyna Impuls, Kraków 2000.

4. Eby J.W., Smutny J.F., Jak ksztatcić uzdolnienia dzieci i młodzieży, tłum. K. Konarzewski, WSiP, Warszawa 1998.

5. Furmanek W., Człowiek. Człowieczeństwo. Wychowanie, FOSZE, Rzeszów 1995.

6. Furmanek W., Walat W. (red.), Problemy wspótczesnej dydaktyki techniki, Wydawnictwo UR, Rzeszów 2003.

7. Głowacki S. (red.) i in., Metoda projektów jako narzędzie integracji międzyprzedmiotowej, Wojewódzki Ośrodek Metodyczny, Kielce 1999.

8. Grondas M., Projekt jako narzędzie integracji międzyprzedmiotowej [w:] Nowa Szkoła. Materiały szkoleniowe dla rad pedagogicznych. Integracja międzyprzedmiotowa, CODN ,Warszawa 1999.

9. Komorowska H., O programach prawie wszystko, WSiP, Warszawa 1999.

10. Królikowski J., Projekt edukacyjny. Materiały dla zespołów międzyprzedmiotowych, CODN, Warszawa 2000.

11. Kwiatkowski S.M. (red.), Kształcenie zawodowe. Rynek pracy. Pracodawcy, IBE, Warszawa 2000.

12. Kwiatkowski S.M. (red.), Nowe uwarunkowania edukacji szkolnej, IBE, Warszawa 1998.

13. Mikina A. (red.), Metoda projektów w ksztaltowaniu przedsiębiorczych postaw uczniów. Przykłady wykorzystania metody projektów na zajęciach języka polskiego, Wojewódzkie Centrum Kształcenia Praktycznego, Łódź 1999. 
14. Nowacki T., O metodzie projektów. ABC nauczyciela szkoły zawodowej, CODN, Warszawa 1996.

15. Průcha J., Pedagogika porównawcza, Wydawnictwo Naukowe PWN, Warszawa 2004.

16. Szymański M.S., O metodzie projektów. Z historii, teorii i praktyki pewnej metody kształcenia, Warszawa 2000.

17. Szymański M.S., Rozprawa o metodzie (projektów) [w:] K. Kruszewski (red.): Pedagogika w pokoju nauczycielskim, WSiP, Warszawa 2000.

18. Wilsz J., Mechanizmy samoregulacji w systemie kształcenia, Wydawnictwo WSP w Rzeszowie, Częstochowa 1996/1997.

\section{Problems at the Development of the Self-initiative of High Schools Trainees}

Among other things education is understood as support of certain individual character traits, e.g. the qualities of a man with self-initiative. It doesn't confine itself to any single action but this is a long process with which should already be started in the youngest years of the life. To obtain an effective support of the self-initiative at high schools trainees, the present general educational system needs either several organizational modifications or modifications of the teaching contents. These refer essentially:

- the teaching programs and their contents

- the principles and the form of the cooperation of the school with the local authority

- the permanent dilatation of the didactic-educational competences of the teachers in the context of further vocational educations.

The specific training in a certain subject should be completed by interdisciplinary trainee projects. The further vocational education of the teachers should take into account the development of the ability to give structured lessons and to better combine the theoretical and practical contents with each other. Furthermore the teachers should be taught how to motivate the trainees for more ownly project drafts and their execution and how the representatives of local authorities should be included in the construction of additional contents of the teaching programs. 